\title{
Pemanfaatan Lingkungan Sekolah Sebagai Sumber Belajar Melalui Supervisi (Pembinaan) Dengan Teknik Diskusi Kelompok Kerja Guru (KKG) Dalam Upaya Peningkatan Kreativitas Guru di SD Negeri 03 Popayato Barat
}

\author{
Selvi Pakaya \\ SD Negeri 03 Popayato Barat \\ selvipakaya@gmail.com
}

\begin{abstract}
Received: 27 March 2021; Revised: 06 June 2021; Accepted: 28 August 2021
DOI: http://dx.doi.org/10.37905/aksara.7.3.865-876.2021
\end{abstract}

\begin{abstract}
Abstrak
Penelitian ini dirancang dalam bentuk Penelitian Tindakan Sekolah yang direncanakan dilaksanakan dalam dua siklus, dimana setiap siklusnya terdiri dari 4tahap yaitu perencanaan, pelaksanaan, observasi dan refleksi. Adapun subyek penelitian ini adalah guru-guru di SD Negeri 03 Popayato Barat yang terdiri dari enam orang guru ASN dan 1 orang guru non ASN. Secara rinci perolehan nilai rata-rata peningkatan kemampuan guru memanfaatkan lingkungan sekolah sebagai sumber belajar yaitu nilai rata-rata observasi hasil kegiatan diskusi 79,43 di siklus I menjadi 85,14 di siklus II ada peningkatan 5,71. Kegiatan penyusunan skenario pembelajaran nilai rata-rata 74,29 di siklus I menjadi 85,71 di siklus II ada peningkatan 11,42. Dan kegiatan pembelajaran atau dalam proses belajar mengajar nilai rata-rata 75,24 di sklus I menjadi 85,71 di siklus II, ada peningkatan 10,47 dalam berdiskusi pada siklus II.. Sehingga dapat disimpulkan bahwa supervisi (pembinaan) melalui teknik diskusi kelompok kerja guru (KKG) dapat meningkatkan kreativitas guru dalam pemanfaatan lingkungan sekolah sebagai sumber belajar bagi guru-guru di SD Negeri 03 Popayato Barat sangat efektif dilakukan.
\end{abstract}

Kata Kunci: Kreativtas guru, Supervisi, Kelompok Kerja Guru

\section{PENDAHULUAN}

Mutu pendidikan dapat ditingkatkan apabila tenaga pengajarannya memiliki kreativitas yang tinggi sesuai dengan apa yang diharapkan dalam dunia pendidikan. Guru yang kreatif harus mampu menciptakan ide-ide, gagasan-gagasan, serta kreasi tebaru di dalam pembelajaran. Kreativitas seorang guru dapat dilihat dari penampilan guru mengajar di kelas dan dalam penentuan sumber belajar serta pemanfaatan lingkungan sebagai sumber belajar yang efektif.

Untuk itu sesuai Kurikulum K-13 yang berlaku sekarang ini, memerlukan strategi baru terutama dalam kegiatan pembelajaran. Pendekatan pembelajaran yang sebelumnya lebih banyak didominasi oleh peran guru (teacher centered) diperbaharui dengan sistem pembelajaran yang berpusat pada siswa (student centered). Dalam implementasi K-13, guru harus mampu memilih dan menerapkan model, motode atau strategi pembelajaran yang sesuai dengan karakteristik materi sehingga mampu mengembangkan daya nalar siswa secara optimal.Dengan demikian dalam pembelajaran 
guru tidak hanya terpaku dengan pembelajaran di dalam kelas, melainkan guru harus mampu melaksanakan pembelajaran dengan motode yang variatif.

Salah satu strategi pembelajaran yang sesuai dengan pendekatan Pakem yang memungkinkan bisa mengembangkan kreativiats, motivasi dan partisipasi siswa dalam pembelajaran adalah dengan pemanfaatan lingkungan sekolah sebagai sumber belajar. Hal ini juga sesuai dengan salah satu pilar dari pendekatan contekstual yaitu masyarakat belajar (learning commonity). Untuk mencapai tujuan tersebut, salah satu cara belajar yang disarankan dalam Kurikulum K-13, sebagai upaya mendekatkan aktivitas belajar siswa pada berbagai fakta kehidupan sehari-hari di sekitar lingkungan siswa. Pemanfaatan lingkungan sekolah sebagai sumber belajar menjadi alternatif setrategi pembelajaran untuk memberikan kedekatan teoritis dan praktis bagi pengembangan hasil belajar siswa secara optimal. Menurut Pantiwati (2015) lingkungan sekolah adalah kesatuan ruang dalam lembaga pendidikan formal yang memberikan pengaruh pembentukan sikap dan pengembangan potensi siswa. Ekowati (2001) mengatakan, pemanfaatan lingkungan sekolah sebagai sumber belajar merupakan bentuk pembelajaran yang berpihak pada pembelajaran melalui penggalian dan penemuan (experiencing) serta keterkaitan (relating) antara materi pelajaran dengan konteks pengalaman kehidupan nyata melalui kegiatan proyek. Pada pembelajaran dengan setrategi ini guru bertindak sebagai pelatih metakognitif yaitu membantu pelajar dalam menemukan materi belajar, mengintegrasikan pengetahuan dan ketrampilan dalam pembuatan laporan dan dalam penampilan hasil dalam bentuk presentasi.

Dari hasil pantauan peneliti selaku kepala Sekolah, ini para guru masih sangat jarang memanfaatkan lingkungan sekolah sebagai sumber belajar. Lingkungan sekolah tidak lebih hanya digunakan sebagai tempat bermain-main siswa pada saat istirahat. Kalau tidak jam istirahat, guru lebih sering memilih mengka-rantina siswa di dalam kelas, walaupun misalnya siswa sudah merasa sangat jenuh berada di dalam kelas.

Melihat kenyataan di atas penulis tergerak untuk mengkaji faktor yang dapat membuat para guru lebih kreatif dalam melaksanakan tugasnya sehari-hari terutama kreatif dalam mengajar, khususnya kreativitas dalam menentukan sumber belajar. Faktor tersebut menyangkut dengan tanggapan guru tehadap bantuan yang diberikan oleh kepala sekolah sebagai supervisor kepada guru-guru. Oleh karena itu kepala sekolah sebagai supervisor perlu menciptakan kerja sama yang solid dan menjalin hubungan kerja yang harmonis sehingga kreativitas seorang guru akan tumbuh dan bekembang menjadi suatu realita di dalam dirinya

Tentunya banyak solusi yang dapat diterapkan dalam mengatasi kendala-kendala yang ada di lapangan, dalam hal ini penulis mengatasi hal tersebut dengan melaksanakan diskusi Kelompok Kerja Guru (KKG) antara para guru kelas melalui supervisi (pembinaan) untuk mendiskusikan masalah pemanfaatan lingkungan sekolah sebagai sumber belajar dalam proses pembelajaran di kelas sehingga nantinya kreatifitas guru dalam proses pembelajaran dapat meningkat.

Dalam kegiatan diskusi tersebut para guru bisa membagi pengalaman dalam pemanfaatan lingkungan sekolah sebagai sumber belajar untuk mencapai hasil belajar yang optimal. Penelitian Nur Mohamad dalam Ekowati (2001) menunjukkan diskusi kolompok memiliki dampak yang amat positif bagi guru yang tingkat pengalamannya rendah maupun yang tingkat pengalamannya tinggi. 
Bagi guru yang tingkat pengalamannya tinggi akan menjadi lebih matang dan bagi guru yang tingkat pengalamannya rendah akan menambah pengetahuan. Keunggulan diskusi kelompok melalui KKG adalah keterlibatan guru bersifat holistic dan konprehensip dalam semua kegiatan. Dari segi lainnya guru dapat menukar pendapat, memberi saran, tanggapan dan berbagai reaksi sosial dengan teman seprofesi sebagai peluang bagi mereka untuk meningkatkan kemampuan dan pengalaman.

\section{KAJIAN PUSTAKA Kreativtas Guru}

Menurut Gullford yang dikutip oleh Utami Munandar, "Kreatifitas melibatkan proses belajar secara divergen, yaitu kemampuan untuk memberikan berbagai alternatif jawaban berdasarkan informasi yang diberikan". Selanjutnya Samiun seperti yang dikutip oleh Retno Indayani menyebutkan kreatifitas adalah "kemampuan untuk membuat kombinasi - kombinasi baru/melihat hubungan - hubungan baru di antara unsur data atau hal - hal yang sudah ada sebelumnya".

Sedangkan kreatifitas menurut Clark Monstakar dalam Utami Munandar menyatakan bahwa kreatifitas adalah "Pengalaman mengekspresikan dan mengaktualisasikan identitas individu dalam bentuk terpadu dalam hubungan dengan diri sendiri, dengan alam, dan dengan orang lain"

Menurut supriyadi yang dikutip oleh Yeni Rahmawati kreatifitas adalah "kemampuan seseorang untuk melahirkan sesuatu yang baru, baik berupa gagasan maupun karya nyata yang relatif berbeda dengan apa yang telah ada. Kreatifitas merupakan kemampuan untuk mengekspresikan dan mewujudkan potensi daya berpikir untuk menghasilkan sesuatu yang baru dan unik/kemampuan mengkombinasikan sesuatu yang sudah ada menjadi sesuatu yang lain agar lebih menarik.

Dari berbagai pandangan tersebut, dapat diartikan bahwa guru yang kreatif adalah guru yang mampu mengaktualisasikan dan mengekspresikan secara optimal segala kemampuan yang ia miliki dalam rangka membina dan mendidik anak didik dengan baik. Seorang guru yang kreatif akan memiliki sikap kepekaan, inisiatif, cara baru dalam mengajar, kepemimpinan serta tanggungjawab yang tinggi dalam pekerjaan dan tugasnya sebagai seorang pendidik

\section{Pemanfaatan Lingkungan Sekolah sebagai Sumber Belajar}

Sumber belajar masyarakat dapat digunakan untuk kepentingan proses pembelajaran sains, ilmu sosial dan yang lainnya, salah satunya melalui survei wilayah. Melalui survei wilayah siswa akan menemukan sumber belajar di masyarakat sehingga mampu menumbuhkan motivasi untuk memperkaya nilai-nilai hasil belajar guna dapat meningkatkan pemahaman dan peningkatan materi pelajaran. (Sarman, $2005: 3$ )

Nilai-nilai kegunaan sumber belajar masyarakat adalah : (1) menghubungkan kurikulum dengan kegiatan-kegiatan masyarakat akan mengembangkan kesadaran dan kepekaan terhadap masalah sosial; (2) menggunakan minat-minat pribadi peserta didik akan menyebabkan belajar lebih bermakna baginya; (3) mempelajari kondisi-kondisi masyarakat merupakan latihan berpikir ilmiah (scientif methode); (4) mempelajari masyarakat akan memperkuat dan memperkaya kurikulum melalui pelaksanaan praktis didalam situasi sesungguhnya; (5) peserta didik memperoleh pengalaman langsung yang kongkrit, realistis dan verbalisme. (Douglas dan Mill dalam Rusyan 2001 : 152) 
Pemanfaatan lingkungan sekolah sebagai sumber belajar mengarahkan anak pada peristiwa atau keadaan yang sebenarnya atau keadaan yang alami sehingga lebih nyata, lebih faktual dan kebenarannya lebih dapat dipertanggungjawabkan.

Manfaat nyata yang dapat diperoleh dengan memanfaatkan lingkungan ini adalah : (1) menyediakan berbagai hal yang dapat dipelajari anak, (2) memungkinkan terjadinya proses belajar yang lebih bermakna (meaningful learning), (3) memungkinkan terjadinya proses pembentukan kepribadian anak, (4) kegiatan belajar akan lebih menarik bagi anak, dan (5) menumbuhkan aktivitas belajar anak (learning aktivities). (Badru Zaman, dkk. 2005)

\section{Supervisi (pembinaan)}

Dalam kaitannya dengan supervisi yang dilakukan oleh Kepala Sekolah, Menurut (Purwanto, 2004:32). Pengertian supervisi adalah "suatu aktivitas pembinaan yang direncanakan untuk membantu para guru dan pegawai sekolah

lainnya dalam melakukan pekerjaan mereka secara efektif' Menurut Jones dalam Mulyasa (2003:155), supervisi merupakan "bagian yang tidak terpisahkan dari seluruh proses administrasi pendidikan yang ditujukan terutama untuk mengembangkan efektivitas kinerja personalia sekolah yang berhubungan tugas -tugas utama pendidikan". Menurut Carter dalam Sahertian (2000:17) supervisiadalah "usaha dari petugas - petugas sekolah dalam memimpin guru - guru dan petugas - petugas lainnya dalam memperbaiki pengajaran, termasuk menstimulasi, menyeleksi pertumbuhan jabatan dan perkembangan guru-guru serta merevisi tujuan-tujuan pendidikan, bahan pengajaran dan metode serta evaluasi pengajaran".

Supervisi adalah aktivitas menentukan kondisi/syarat-syarat yang essensial yang akan menjamin tercapainya tujuan-tujuan pendidikan. Dari definisi tersebut maka tugas kepala sekolah sebagai supervisor berarti bahwa dia hendaknya pandai meneliti, mencari, dan menentukan syarat-syarat mana sajakah yang diperlukan bagi kemajuan sekolahnya sehingga tujuan - tujuan pendidikan di sekolah itu semaksimal mungkin dapat tercapai

Menurut Mulyasa (2004:112) salah satu supervisi akademik yang populer adalah supervisi klinis, yang memiliki karakteristik sebagai berikut:

1. Supervisi diberikan berupa bantuan (bukan perintah), sehingga inisiatif tetap berada di tangan tenaga kependidikan.

2. Aspek yang disupervisi berdasarkan usul guru, yang dikaji bersama kepala sekolah sebagai supervisor untuk dijadikan kesepakatan.

3. Instrumen dan metode observasi dikembangkan bersama oleh guru dan Kepala Sekolah.

4. Mendiskusikan dan menafsirkan hasil pengamatan dengan mendahulukan interpretasi guru.

5. Supervisi dilakukan dalam suasana terbuka secara tatap muka, dan supervisor lebih banyak mendengarkan serta menjawab pertanyaan guru daripada memberi saran dan pengarahan.

6. Supervisi klinis sedikitnya memiliki tiga tahap, yaitu pertemuan awal, pengamatan, dan umpan balik.

7. Adanya penguatan dan umpan balik dari kepala sekolah sebagai supervisor terhadap perubahan perilaku guru yang positif sebagai hasil pembinaan Supervisi 
dilakukan secara berkelanjutan untuk meningkatkan suatu keadaan dan memecahkan suatu masalah.

Dari uraian di atas dapat disimpulkan bahwa supervisi klinis lebih berorientasi kepada penemuan masalah secara obyektif. Masalah tersebut bukan untuk menekan bawahan,akan tetapi untuk dianalisis dan dilakukan pemecahan masalah (problem solving) secara bersama-sama

\section{Kelompok Kerja Guru (KKG)}

Kelompok Kerja Guru (KKG) adalah bentuk kegiatan yang beranggotakan guruguru kelas, dimana tujuan kegiatannya adalah untuk meningkatkan kemampuan dan kompetensi mereka sesuai kelas yang dipegang. Bentuk kegiatan KKG bisa berupa diklat, simulasi, diskusi atau yang lainnya.

Kemudian diskusi kelompok adalah suatu kegiatan belajar yang dilakukan secara bersama-sama. Diskusi kelompok pada dasarnya memecahkan persoalan secara bersama-sama. Artinya setiap anggota turut memberikan sumbangan pemikiran dan pendapat dalam memecahkan persoalan tersebut. Diskusi kelompok adalah suatu kegiatan belajar untuk memecahkan persoalan secara bersama-sama, sehingga akan memperoleh hasil yang lebih baik. (Tabrani dan Daryani dalam Kasianto,2004)

Berdasarkan uraian diatas, dapat disimpulkan bahwa diskusi kelompok adalah suatu proses usaha yang dilakukan individu untuk memperoleh perubahan tingkah laku sebagai pengalaman individu dalam interaksinya dengan lingkungan yang dilakukan secara bersama-sama atau berkelompok.

Ischak.SW dan Warji R. (dalam Kasianto,2004) mengemukakan beberapa petunjuk dalam pelaksanaan diskusi kelompok, yaitu :

a. Pilihlah teman yang cocok untuk bergabung dalam belajar kelompok. Jumlah setiap kelompok terdiri dari 5 hingga 7 orang.

b. Tetapkan siapa sebagai pemimpin yang akan memimpin jalannya diskusi atau belajar kelompok.

c. Hentaskan persoalan satu persatu dengan memberi kesempatan kepada anggota untuk mengajukan pendapatnya. Dari pendapat yang masuk dikaji bersama-sama mana yang paling tepat. (Ischak.SW dan Warji R. dalam Kasianto,2004)

Dari uraian di atas,maka di dalam pelaksanaan diskusi kelompok perlu diperhatikan pembentukan kelompok,penetapan pimpinan kelompok,penetapan masalah yang akan dibahas dan pencatatan kesimpulan hasil diskusi kelompok.

\section{METODE}

Lokasi Penelitian di SD Negeri 03 Popayato Barat di jalan trans sulawesi desa persatuan Kecamatan Popyato Barat Kabupaten Pohuwato yang ditujukan pada guruguru untuk pengamatan terhadap peningkatan kreativitas guru dalam memanfaatkan lingkungan sekolah sebagai sumber belajar.

Subyek Penelitian ini adalah 1 orang guru mata pelajaran dan 6 orang guru kelas yang terdiri dari 6 orang PNS dan 1 orang honor. Dari 7 orang guru tersebut akan dilihat perkembanganya setelah dilakukan tindakan yang dimulai dari siklus I dan II

Penelitian ini adalah Penelitian Tindakan Sekolah (PTS) sehingga dalam pelaksanaannya menekankan pada peningkatan profesionalitas guru dalam 
memanfaatkan lingkungan sebagai sumber belajar. Bentuk tindakan dalam penelitian ini berupa supervisi akademik melalui diskusi Kelompok Kerja Guru (KKG) kepada guru kelas dan guru mata pelajaran, agar mampu menyusun skenario pembelajaran dan pelaksanaan pembelajaran dengan memanfaatkan lingkungan sekolah sebagai sumber belajar secara efektif. Secara rinci bentuk tindakan dalam penelitian ini adalah :

1. Menyampaikan informasi tentang pemanfaatan lingkungan sekolah sebagai sumber belajar.

2. Membimbing guru menyusun skenario pembelajaran yang berkaitan dengan pemanfaatan lingkungan sekolah sebagai sumber belajar.

3. Membimbing guru dalam memanfaatkan lingkungan sekolah sebagai sumber belajar.

4. Membimbing guru dalam melaksanakan pembelajaran dengan memanfaatkan lingkungan sekolah sebagai sumber belajar.

\section{HASIL PENELITIAN}

\section{Siklus I}

a. Perencanaan penelitian meliputi:

1) Pertemuan dengan Kepala Sekolah dan guru - guru, menginformasikan tentang pelaksanaan penelitian.

2) Peneliti menyiapkan skenario diskusi kelompok kerja guru (KKG) tentang permasalahan yang dihadapi dalam pemanfaatan lingkungan madrasah/sekolah sebagai sumber belajar yang akan dilaksanakan selama proses tindakan.

3) Peneliti menyiapkan instrumen penelitian (lembar observasi, lembar penilaian kemampuan guru).

b. Pelaksanaan Penelitian.

Pada tahap pelaksanaan merupakan tahap inti dimana pelaksanaan supervisi berlangsung dengan langkah-langkah berikut.

Pertemuan I

Peneliti selaku kepala sekolah memberi arahan umum pemanfaatan lingkungan sekolah sebagai sumber belajar bagi siswa dan implementasinya dalam proses belajar mengajar

Pertemuan II

(a). Guru melaksanakan pembelajaran dengan memanfaatkan lingkungan sekolah sebagai sumber belajar sesuai skenario pembelajaran yang dimiliki.

(b). Peneliti melakukan penilaian pada guru terkait dengan implementasi pembelajaran sesuai skenario yang dibuat.

\section{Pertemuan III}

(a) Kepala sekolah dalam supervisi akademik melakukan diskusi tentang kendala kendala pelaksanakan pembelajaran dengan memanfaatkan lingkungan sekolah sebagai sumber belajar.

(b) Peneliti melakukan bimbingan dalam kelompok, terkait dengan pembelajaran yang diterapkan guru. dan merevisi skenario pembelajaran sehingga menghasilkan skenario pembelajaran yang sesuai dengan pakem.

c. Observasi dan Evaluasi

Kegiatan observasi dilaksanakan bersamaan dengan pelaksanaan tindakan yaitu pada saat supervisi baik pada pertemuan I, II dan III. Tahap observasi bertujuan untuk mengetahui kerjasama, kreativitas, perhatian, maupun presentasi yang dilakukan guru dalam menyusun skenario pembelajaran maupun dalam melaksanakan pembelajaran 
dengan memanfaatkan lingkungan sekolah sebagai sumber belajar. Pelaksanaan observasi dilakukan dengan menggunakan lembar observasi.

Tabel 1

Data Hasil Observasi

\begin{tabular}{|c|l|c|c|c|c|c|c|}
\hline \multirow{2}{*}{ No } & \multirow{2}{*}{ Nama Guru } & \multicolumn{4}{|c|}{ Aspek Yang Di Observasi } & Skor & \\
\cline { 3 - 7 } & & Kerjasama & Aktivitas & Perhatian & Preesntasi & Maks & \multirow{2}{*}{ Kategori } \\
\cline { 3 - 7 } & $1-10$ & $1-40$ & $1-20$ & $1-30$ & 100 & \\
\hline 1 & S. D. Radji & 8 & 30 & 15 & 27 & 80 & Baik \\
\hline 2 & A. Tuli & 8 & 30 & 16 & 26 & 80 & Baik \\
\hline 3 & L. N. Indahsari & 8 & 30 & 15 & 27 & 80 & Baik \\
\hline 4 & S. M.Barham & 8 & 31 & 15 & 26 & 80 & Baik \\
\hline 5 & W. Kuense & 8 & 33 & 16 & 22 & 79 & Cukup \\
\hline 6 & M. Hadjura & 8 & 30 & 16 & 26 & 80 & Baik \\
\hline 7 & A.E. Polohi & 8 & 30 & 14 & 25 & 77 & Cukup \\
\hline & Jumlah & 56 & 214 & 107 & 179 & 556 & \multirow{2}{*}{ Cukup } \\
\hline
\end{tabular}

Data penelitian tindakan sekolah yang diperoleh dari hasil observasi sikap guru dalam kegiatan diskusi kelompok kerja guru tentang pemanfaatan lingkungan sekolah sebagai sumber belajar pada siklus I, hasilnya termasuk kategori "cukup" dengan ratarata nilai 79,43 . Hal ini menunjukan bahwa guru dalam berdiskusi belum menampakkan kerjasama, aktivitas dan perhatian yang baik terhadap permasalahan pemanfaatan lingkungan sekolah sebagai sumber belajar, sehingga diperlukan bimbingan yang lebih intensif.

Evaluasi dilakukan pada akhir pertemuan siklus I, dengan menggunakan format penilaian terhadap skenario pembelajaran dan penilaian pelaksanaan pembelajaran. Penilaian terhadap skenario pembelajaran dalam bentuk program perencanaan pelaksanaan pembelajaran (RPP) yang disusun guru dalam siklus I, didapatkan hasil sebagai berikut :

Tabel 2.

Data Hasil Penilaian Skenario Pembelajaran

\begin{tabular}{|c|l|c|c|c|c|c|c|c|}
\hline \multirow{2}{*}{ No } & \multirow{2}{*}{ Nama Guru } & \multicolumn{3}{|c|}{ Aspek Yang Dinilai } & Jumlah & Jumlah & \multirow{2}{*}{ Kategori } \\
\cline { 3 - 7 } & & 1 & 2 & 3 & 4 & Skor & Nilai & \\
\hline 1 & S. D. Radji & 4 & 3 & 4 & 5 & 16 & 80 & Baik \\
\hline 2 & A. Tuli & 5 & 4 & 3 & 3 & 15 & 75 & Cukup \\
\hline 3 & L. N. Indahsari & 3 & 4 & 3 & 4 & 14 & 70 & Cukup \\
\hline 4 & S. M.Barham & 5 & 4 & 4 & 3 & 16 & 80 & Baik \\
\hline 5 & W. Kuense & 4 & 3 & 3 & 4 & 14 & 70 & Cukup \\
\hline 6 & M. Hadjura & 3 & 4 & 4 & 5 & 16 & 80 & Baik \\
\hline 7 & A.E. Polohi & 4 & 3 & 3 & 3 & 13 & 65 & Cukup \\
\hline \multicolumn{2}{r|}{ Jumlah } & 28 & 25 & 24 & 27 & 104 & 520 & \multirow{2}{*}{ Cukup } \\
\hline
\end{tabular}

Keterangan

Aspek 1 Jenis sumber belajar dari lingkungan sekolah 
Aspek 2 Kesesuaian antara materi pelajaran dengan media pembelajaran Aspek 3 Kesesuaian antara materi pelajaran dengan strategi pembelajaran Aspek 4 Kesesuaian antara tujuan pembelajaran dengan sumber bahan

Penilaian skenario pembelajaran yang berbentuk rencana pelaksanaan pembelajaran (RPP) hasilnya termasuk kategori "cukup" dengan rata-rata nilai 74,29. Hal ini menunjukkan bahwa kreativitas guru dalam menyusun skenario pembelajaran dengan pemanfaatan lingkungan sekolah sebagai sumber belajar perlu peningkatan

Sedangkan penilaian implementasi pemanfaatan lingkungan sekolah sebagai sumber belajar dalam kegiatan pembelajaran di kelas pada siklus I didapatkan hasil sebagai berikut

Tabel 3

Data Hasil Penilaian Pelaksanaan Pembelajaran

\begin{tabular}{|c|c|c|c|c|c|c|c|c|c|c|}
\hline \multirow{2}{*}{ No } & \multirow{2}{*}{ Nama Guru } & \multicolumn{6}{|c|}{ Aspek Yang Dinilai } & \multirow{2}{*}{$\begin{array}{l}\text { Jumlah } \\
\text { Skor }\end{array}$} & \multirow{2}{*}{$\begin{array}{c}\text { Jumlah } \\
\text { Nilai }\end{array}$} & \multirow{2}{*}{ Kategor } \\
\hline & & 1 & 2 & 3 & 4 & 5 & 6 & & & \\
\hline 1 & S. D. Radji & 5 & 4 & 4 & 3 & 4 & 4 & 24 & 80,00 & Baik \\
\hline 2 & A. Tuli & 4 & 3 & 4 & 4 & 3 & 3 & 21 & 70,00 & Cukup \\
\hline 3 & L. N. Indahsari & 5 & 4 & 3 & 4 & 4 & 5 & 25 & 83,33 & Baik \\
\hline 4 & S. M.Barham & 3 & 3 & 4 & 3 & 3 & 4 & 20 & 66,67 & Cukup \\
\hline 5 & W. Kuense & 5 & 4 & 3 & 4 & 4 & 5 & 25 & 83,33 & Baik \\
\hline 6 & M. Hadjura & 3 & 4 & 4 & 3 & 4 & 4 & 22 & 73,33 & Cukup \\
\hline 7 & A.E. Polohi & 4 & 4 & 3 & 4 & 3 & 3 & 21 & 70,00 & Cukup \\
\hline & Jumlah & 29 & 26 & 25 & 25 & 25 & 28 & 158 & 526,67 & \multirow{2}{*}{ Cukup } \\
\hline & Rata - rata & 4,14 & 3,71 & 3,57 & 3,57 & 3,57 & 4,00 & 22,57 & 75,24 & \\
\hline
\end{tabular}

Keterangan

Aspek 1 Kegiatan awal

Aspek 2 Kegiatan inti,

Aspek 3 Kemampuan guru mengkaitkan materi pelajaran dengan lingkungan sekolah

Aspek 4 Kemampuan guru mengkaitkan materi pelajaran dengan media pembelajaran

Aspek 5 Kemampuan guru mengkaitkan materi pelajaran dengan strategi sekolah

Aspek 6 Penutup pelajaran

Penilaian implementasi pemanfaatan lingkungan sekolah sebagai sumber belajar dalam kegiatan pembelajaran di kelas, hasilnya termasuk katagori "cukup" dengan ratarata nilai 75,24 Hal ini menunjukkan bahwa guru dalam mengimplementasikan pemanfaatan lingkungan sekolah sebagai sumber belajar melalui kegiatan pembelajaran di kelas belum optimal, sehingga perlu peningkatan.

d. Refleksi

Dengan adanya hasil obser-vasi dan penilaian pada kegiatan siklus I maka peneliti melakukan refleksi. Dari refleksi terhadap seluruh kegiatan pada siklus I, maka ditemukan beberapa hambatan yang mengakibatkan belum optimalnya kemampuan guru memanfaatkan lingkungan sekolah sebagai sumber belajar.

\section{Siklus II}

a. Perencanaan Penelitian. 
Pada tahap ini direncanakan supervisi (pembinaan) dengan menggunakan tehnik diskusi kelompok kerja guru (KKG), tentang pemanfaatan lingkungan sekolah sebagai sumber belajar oleh guru kelas maupun guru mata pelajaran di SD Negeri 03 Popayato Barat yang belum mencapai hasil optimal dalam siklus I.

Berdasarkan hasil observasi dan refleksi siklus I, dilakukan perbaikan terhadap strategi dan penyempurnaan pelaksanaan bimbingan di siklus II.

b. Pelaksanaan Penelitian.

Pada prinsipnya langkah - langkah pelaksanaan tindakan pada siklus I diulang pada siklus II dengan memodifikasi dan perbaikan-perbaikan berdasarkan hasil refleksi pada siklus I. Kegiatan pada siklus II terdiri dari 2 (dua) kali pertemuan dengan mengikuti langkah - langkah sebagai berikut :

\section{Pertemuan I}

1) Melalui supervisi, guru mendiskusikan tentang permasalahan permasalahan atau hambatan memanfaatkan lingkungan sekolah sebagai sumber belajar,dalam menyusun skenario pembelajaran yang selanjutnya dicarikan pemecahannya. Kegiatan ini dibantu oleh guru yang dianggap sudah cukup mampu dalam hal tersebut..

2) Guru mempresentasikan dan mensimulasikan hasil diskusi kelompoknya.

3) Guru merevisi dan menyempurnakan skenario pembelajaran dengan mengoptimalkan pemanfaatan lingkungan sekolah sebagai sumber belajar.

\section{Pertemuan II}

1) Guru melaksanakan kegiatan belajar mengajar di kelas dengan menggunakan skenario pembelajaran yang sudah direvisi.

2) Guru mendiskusikan dan menyempurnakan skenario pembelajaran yang lengkap dengan pemanfaatan lingkungan sekolah sebagai sumber belajar.

3) Guru mencatat kekurangan pembelajaran yang perlu diperbaiki dan disempurnakan. c. Observasi dan Evaluasi.

Observasi dilakukan peneliti saat guru berdiskusi tentang masalah atau hambatan dan pemecahannya dalam kegiatan kelompok kerja guru baik secara individu maupun kelompok. Observasi terhadap aspek sikap guru dilakukan dengan menggunakan format observasi yang sama dengan format observasi yang digunakan pada siklus I.

Tabel 4

Data Hasil Observasi

\begin{tabular}{|c|c|c|c|c|c|c|c|}
\hline \multirow{3}{*}{ No } & \multirow{3}{*}{ Nama Guru } & \multicolumn{4}{|c|}{ Aspek Yang Di Observasi } & \multirow{3}{*}{$\begin{array}{c}\text { Skor } \\
\text { Maks } \\
100\end{array}$} & \multirow{3}{*}{ Kategori } \\
\hline & & Kerjasama & Aktivitas & Perhatian & Preesntasi & & \\
\hline & & $1-10$ & $1-40$ & $1-20$ & $1-30$ & & \\
\hline 1 & S. D. Radji & 8 & 35 & 15 & 28 & 86 & Baik \\
\hline 2 & A. Tuli & 8 & 33 & 16 & 26 & 83 & Baik \\
\hline 3 & L. N. Indahsari & 8 & 38 & 18 & 28 & 92 & Amat Baik \\
\hline 4 & S. M.Barham & 8 & 35 & 15 & 26 & 84 & Baik \\
\hline 5 & W. Kuense & 8 & 33 & 16 & 27 & 84 & Baik \\
\hline 6 & M. Hadjura & 8 & 32 & 16 & 26 & 82 & Baik \\
\hline 7 & A.E. Polohi & 8 & 36 & 14 & 27 & 85 & Baik \\
\hline & Jumlah & 56 & 242 & 110 & 188 & 596 & \multirow{2}{*}{ Baik } \\
\hline & Rata - rata & 8 & 34,57 & 15,71 & 26,86 & 85,14 & \\
\hline
\end{tabular}


Hasil observasi terhadap sikap guru pada siklus II, setelah dianalisis ada peningkatan kearah perbaikan yaitu berada pada katagori "baik", dengan rata-rata nilai 85,14

Evaluasi dilakukan pada akhir pertemuan siklus II,dengan menggunakan format penilaian yang sama dengan format penilaian yang digunakan pada siklus I. Adapun aspek yang dinilai, serta cara menilai juga sama dengan penilaian pada siklus I.

Tabel 5

Data Hasil Penilaian Skenario Pembelajaran

\begin{tabular}{|c|c|c|c|c|c|c|c|c|}
\hline \multirow{2}{*}{ No } & \multirow{2}{*}{ Nama Guru } & \multicolumn{3}{|c|}{ Aspek Yang Dinilai } & Jumlah & Jumlah & \multirow{2}{*}{ Kategori } \\
\cline { 3 - 8 } & & 1 & 2 & 3 & 4 & Skor & Nilai & \\
\hline 1 & S. D. Radji & 4 & 4 & 4 & 5 & 17 & 85 & Baik \\
\hline 2 & A. Tuli & 5 & 4 & 4 & 4 & 17 & 85 & Cukup \\
\hline 3 & L. N. Indahsari & 4 & 4 & 5 & 4 & 17 & 85 & Cukup \\
\hline 4 & S. M.Barham & 5 & 4 & 3 & 5 & 17 & 85 & Baik \\
\hline 5 & W. Kuense & 4 & 5 & 4 & 4 & 17 & 85 & Cukup \\
\hline 6 & M. Hadjura & 5 & 4 & 4 & 5 & 18 & 90 & Baik \\
\hline 7 & A.E. Polohi & 4 & 5 & 4 & 4 & 17 & 85 & Cukup \\
\hline & Jumlah & 31 & 30 & 28 & 31 & 120 & 600 & \multirow{2}{*}{ Cukup } \\
\hline
\end{tabular}

Keterangan

Aspek 1 Jenis sumber belajar dari lingkungan sekolah

Aspek 2 Kesesuaian antara materi pelajaran dengan media pembelajaran

Aspek 3 Kesesuaian antara materi pelajaran dengan strategi pembelajaran

Aspek 4 Kesesuaian antara tujuan pembelajaran dengan sumber bahan

Sedangkan penilaian implementasi pemanfaatan lingkungan sekolah sebagai sumber belajar dalam kegiatan pembelajaran di kelas pada siklus II didapatkan hasil sebagai berikut

Tabel 6

Data Hasil Penilaian Pelaksanaan Pembelajaran

\begin{tabular}{|c|c|c|c|c|c|c|c|c|c|c|}
\hline \multirow{2}{*}{ No } & \multirow{2}{*}{ Nama Guru } & \multicolumn{6}{|c|}{ Aspek Yang Dinilai } & \multirow{2}{*}{$\begin{array}{c}\text { Jumlah } \\
\text { Skor }\end{array}$} & \multirow{2}{*}{$\begin{array}{c}\text { Jumlah } \\
\text { Nilai }\end{array}$} & \multirow{2}{*}{ Kategori } \\
\hline & & 1 & 2 & 3 & 4 & 5 & 6 & & & \\
\hline 1 & S. D. Radji & 5 & 4 & 5 & 3 & 4 & 4 & 25 & 83,33 & Baik \\
\hline 2 & A. Tuli & 4 & 5 & 4 & 4 & 4 & 3 & 24 & 80,00 & Baik \\
\hline 3 & L. N. Indahsari & 5 & 4 & 3 & 4 & 5 & 5 & 26 & 86,67 & Baik \\
\hline 4 & S. M.Barham & 4 & 4 & 4 & 5 & 3 & 5 & 25 & 83,33 & Baik \\
\hline 5 & W. Kuense & 5 & 4 & 4 & 5 & 4 & 5 & 27 & 90,00 & Amat Baik \\
\hline 6 & M. Hadjura & 4 & 5 & 5 & 4 & 5 & 4 & 27 & 90,00 & Amat Baik \\
\hline 7 & A.E. Polohi & 5 & 4 & 4 & 5 & 4 & 4 & 26 & 86,67 & Baik \\
\hline & Jumlah & 32 & 30 & 29 & 30 & 29 & 30 & 180 & 600 & \multirow{2}{*}{ Baik } \\
\hline & Rata - rata & 4,57 & 4,29 & 4,14 & 4,29 & 4,14 & 4,29 & 25,71 & 85,71 & \\
\hline
\end{tabular}

Keterangan

Aspek 1 Kegiatan awal

Aspek 2 Kegiatan inti, 
Aspek 3 Kemampuan guru mengkaitkan materi pelajaran dengan lingkungan sekolah Aspek 4 Kemampuan guru mengkaitkan materi pelajaran dengan media pembelajaran Aspek 5 Kemampuan guru mengkaitkan materi pelajaran dengan strategi sekolah Aspek 6 Penutup pelajaran

Untuk penilaian skenario pembelajaran dan penilaian pelaksanaan pembelajaran,masing-masing juga ada peningkatan yang ke arah yang lebih baik yaitu: untuk skenario pembelajaran dan untuk penilaian pelaksanaan pembelajaran di kelas berada pada katagori "baik" dengan masing masing nilai rata-ratanya adalah 85,71 d. Refleksi

Dengan melihat hasil pada siklus II, maka refleksi terhadap hasil yang diperoleh peneliti pada siklus II ini adalah adanya peningkatan kemampuan guru memanfaatkan lingkungan sekolah sebagai sumber belajar. Hal ini dibuktikan dengan nilai rata-rata yang diperoleh dalam memprogramkan pembelajaran serta dalam implementasinya di kelas yang sudah menunjukkan adanya peningkatan kemampuan guru untuk memanfaatkan lingkungan sekolah sebagai sumber belajar yang lebih baik. Sedangkan dari jumlah guru ,75\% sudah mencapai kriteria yang ditetapkan.

\section{PEMBAHASAN}

Secara rinci perolehan nilai rata-rata peningkatan kemampuan guru memanfaatkan lingkungan sekolah sebagai sumber belajar yaitu nilai rata-rata observasi hasil kegiatan diskusi 79,43 di siklus I menjadi 85,14 di siklus II ada peningkatan 5,71. Kegiatan penyusunan skenario pembelajaran nilai rata-rata 74,29 di siklus I menjadi 85,71 di siklus II ada peningkatan 11,42. Dan kegiatan pembelajaran atau dalam proses belajar mengajar nilai rata-rata 75,24 di sklus I menjadi 85,71 di siklus II, ada peningkatan 10,47 dalam berdiskusi pada siklus II. Keseluruhan hasil pada penelitian ini disajikan dalam diagram berikut ini

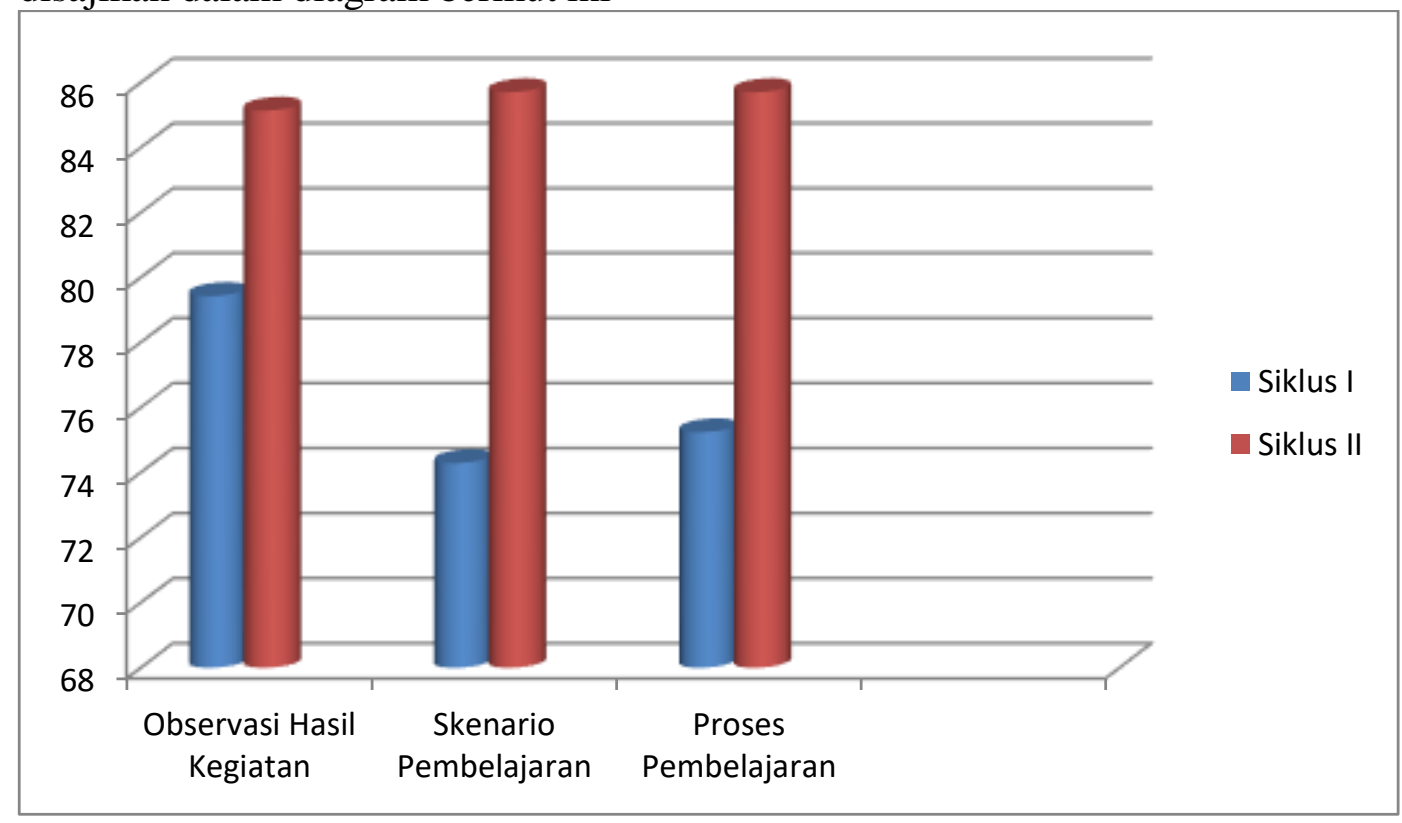

Gambar 1

Diagram Hasil Penelitian Siklus I dan Siklus II 
Dari hasil paparan pada diagram diatas nampak suatu keberhasilan yang dicapai guru setelah dilakukan supervisi melalui teknik diskusi Kelompok Kerja Guru (KKG). Pelaksanaan supervisi melalui teknik diskusi Kelompok Kerja Guru (KKG) terbukti mampu memberikan wawasan kepada guru kelas dan guru mata pelajaran dalam rangka meningkatkan kreativitas untuk pemanfaatan lingkungan sekolah sebagai sumber belajar. Setelah dilakukan evaluasi maka hasil Penelitian Tindakan Sekolah yang dilaksanakan di SD Negeri 03 Popayato Barat berhasil dengan baik

\section{Kesimpulan}

Berdasarkan hasil analisis dan pembahasan siklus I dan siklus II dapat disimpulkan bahwa:

1. Ada peningkatan kemampuan kreativitas guru dalam menyusun dan melaksanakan skenario pembelajaran serta memanfaatkan lingkungan sekolah sebagai sumber belajar melalui supervisi dengan teknik diskusi kelompok kerja guru (KKG) di SD Negeri 03 Popayato Barat yang dilaksanakan dan dibimbing Kepala Sekolah.

2. Dengan memanfaatkan kelebihan supervisi dan diskusi dalam kelompok kerja guru (KKG), akan dapat memecahkan masalah yang dihadapi guru terutama yang berkaitan dengan penyusunan rencana dan melaksanakan pembelajaran serta pemanfaatan lingkungan sekolah sebagai sumber belajar dalam proses pembelajaran di SD Negeri 03 Popayato Barat

\section{DAFTAR PUSTAKA}

Cece, Wijaya. 1992. Kemampuan Guru dalam Proses Belajar Mengajar. Bandung: Remaja Rosda Karya.

Danim, S. 2002. Menjadi Peneliti Kualitatif. Bandung: Pustaka Setia

Dede, Rosyada. 2004. Paradigma Pendidikan Demokratis. Jakarta: Kencana.

Ibrahim, Bafadal. 2003. Peningkatan Profesionalisme Guru Sekolah Dasar. Jakarta: Bumi Aksara.

Mulyasa,E. 2004. Menjadi Kepala Sekolah Profesional. Bandung: Remaja Rosdakarya

Pidarta, M. 1999. Peranan Kepala Sekolah Pada Pendidikan Dasar: Seri Manajemen Pendidikan. Jakarta: Grasindo

Purwanto,M.Ngalim. 2004. Administrasi dan Supervisi Pendidikan. Bandung: Remaja Rosdakarya

Retno Indayani. 2002. Kreatifitas Guru dalam Proses Pembelajaran. Tulungagung: STAIN Tulungagung

Tabrani, Rusyan. 1993. Peningkatan Kemampuan Guru Pendidikan Dasar. Bandung: Bina Budaya

Sahertian. 2000. Supervisi Pendidikan. Jakarta: Reneke

Sutrisno. Hadi. 2000. Metodologi Penelitian. Yogyakarta: Andi 